\title{
SEMI-DRY GRASSLAND RESTORATION IN THE SE ALPINE FORELAND OF AUSTRIA - A STUDY OF EARLY SPONTANEOUS COLONISATION PATTERNS
}

\author{
Philipp SENGL ${ }^{1, *}$, Viktoria WAGNER ${ }^{2} \&$ Martin MAGNES $^{1}$
}

\begin{abstract}
We investigated early spontaneous colonisation patterns during semi-dry grassland restoration at two sites in SE Austria. The sites were left to regenerate passively without addition of plant propagules on a former arable field and an apple orchard. The sites were prepared only by ploughing (arable field) or clear cutting (apple orchard) and subsequently mowed annually. We studied whether, four years after project initiation, target species from adjacent semi-dry grasslands had established at the restored sites. We asked: 1) Does passive restoration lead to the establishment of target species? 2) Do abiotic parameters or distance to reference sites explain early colonisation patterns? 3 ) Do plant traits predict the colonisation success of different species? At each site, we collected data in $4 \mathrm{~m} \times 4 \mathrm{~m}$ plots, in which we sampled the vegetation, analysed abiotic parameters (soil potassium- and phosphorus-content, soil-pH, slope) and recorded the minimum distance to the reference site. We tested for correlations between abiotic variables, plant traits and colonisation success. Colonisation patterns were not driven by abiotic soil conditions but rather by nearest distance to the reference sites. In addition, the vegetation developed differently in the former arable field and the apple orchard. Competitive species of the Arrhenatherion and thermophilic ruderal associations dominated the early restoration stage at both sites. Passive restoration of semi-dry grasslands on former agricultural land is unlikely to succeed unless complemented by initial ploughing, nutrient stripping and addition of propagules of rare species.
\end{abstract}

Keywords: colonisation success, ecological strategy, Festuco-Brometea, plant trait, secondary succession, Styria.

\section{Izvleček}

Preučevali smo vzorce zgodnje naselitve vrst med obnovo polsuhih travišč na dveh lokacijah v jugovzhodni Avstriji. Travišča smo prepustili pasivni obnovi brez vnosa propagul na nekdanjo obdelano površino in sadovnjak jablan. Obe površini smo predhodno obdelali tako, da smo polje preorali, sadovnjak pa posekali in nato kosili vsako leto. Po štirih letih od začetka projekta smo spremljali, ali se na obnovljenih površinah pojavljajo tarčne vrste s sosednjih polsuhih travišč. Zanimalo nas je: 1) Ali pasivna obnova omogoča naselitev tarčnih vrst? 2) Ali lahko z abiotskimi dejavniki ali oddaljenostjo ciljnega travišča razložimo vzorce zgodnje naselitve? 3) Ali lahko z rastlinskimi znaki napovemo uspešnost naselitve različnih vrst? Na vsaki lokaciji smo postavili poskusne ploskve $4 \mathrm{~m} \times 4 \mathrm{~m}$, kjer smo vzorčili vegetacijo, abiotske dejavnike (vsebost kalija in fosforja $\mathrm{v}$ tleh, $\mathrm{pH}$ tal, naklon) in izmerili minimalno oddaljenost od ciljnega travišča. Testirali smo korelacijo med abiotskimi dejavniki, rastlinskimi znaki in uspešnostjo naselitve vrst. Vzorci kolonizacije so bolj odvisni od bližine ciljnega travišča kot pa od abiotskih dejavnikov tal, poleg tega se je vegetacija razvijala drugače na nekdanji njivi kot v sadovnjaku. Na obeh rastiščih so $\mathrm{v}$ zgodnjih fazah obnove prevladovale konkurenčno uspešnejše vrste zveze Arrhenatherion in termofilnih ruderalnih združb. Pasivna obnova polsuhih travišč na nekdanjih obdelovanih površinah bo verjetno neuspešna brez predhodnega oranja, odstranjevanja hranil in dodajanja propagul redkih vrst.

Ključne besede: uspešnost naselitve, ekološka strategija, Festuco-Brometea, rastlinski znaki, sekundarna sukcesija, Štajerska.

\footnotetext{
${ }^{1}$ Institute of Plant Sciences, University of Graz, Holteigasse 6, 8010 Graz, Austria. E-mail: martin.magnes@uni-graz.at, nwsephi@gmx.at

${ }^{2}$ Department of Botany and Zoology, Masaryk University, Kotlářská 2, 61137 Brno, Czech Republic. E-mail: wagner@ sci.muni.cz

* Corresponding author: nwsephi@gmx.at
} 


\section{INTRODUCTION}

Semi-dry grasslands are critically endangered in many European regions (Fischer \& Stöcklin 1997, Hansson \& Fogelfors 2000, Kahmen et al. 2002, WallisDeVries et al. 2002, Dostálek \& Frantík 2008, Habel et al. 2013, Pipenbaher et al. 2013). This is particularly true for the SE Alpine foreland of Austria where only few sites remain (Steinbuch 1995, Essl et al. 2004), scattered among intensively managed agricultural fields. Despite their decline, semi-dry grassland fragments are still important hotspots of biodiversity (Di Pietro 2011, Wilson et al. 2012, Habel et al. 2013). In SE Austria, they harbour up to 83 plant species on $25 \mathrm{~m}^{2}$ (Sengl \& Magnes 2008) and provide valuable habitats for various groups of organisms, especially arthropods such as beetles, solitary bees, ants and grasshoppers (Gepp 1986).

In restoration ecology, succession dynamics are usually studied in the form of spontaneous colonisation after abandonment of grasslands or arable fields (e.g. Bartha et al. 2003, Kahmen \& Poschlod 2004, Jírová et al. 2012, Paušič \& Čarni 2012) or mining sites (e.g. Kirmer \& Mahn 2001, Trnková et al. 2010, Prach et al. 2013, Tischew et al. 2013). These studies used different study designs, making it difficult to draw general conclusions about the mechanisms behind early colonisation. However, many of them have shown abiotic site factors to be important predictors for the establishment of target plants. The spatial proximity to propagule-donor site appears to be similarly important. Even if soil conditions are good, restoration will fail if propagule-donor sites are not found nearby.

Despite this progress, few studies have investigated spontaneous colonisation patterns during passive restoration of grassland sites that are subject to traditional meadow management (Conrad \& Tischew 2011). Nevertheless, several studies have shown that this $<$ passive $>$ restoration method can be an efficient and cost effective way to trigger the establishment of target species (Donath et al. 2003, Ruprecht 2006, Fagan et al. 2008, Prach \& Hobbs 2008, Török et al. 2011). However, a necessary prerequisite is that appropriate propagule donor sites are nearby and that sites are not endangered by erosion or high propagule pressure by weeds (Kirmer et al. 2012).

In order to foster the restoration of speciesrich semi-dry grasslands in the region, the Natur- schutzbund Steiermark, a non-profit regional organisation, acquired an arable field (AF, former Zea mays cultivation) and apple orchard ( $\mathrm{AO}$, former Malus domestica cultivation). Due to financial constraints, no plant propagule material was applied to the restoration sites after initial site preparation. Instead, the project aimed to exploit the fact that both sites bordered on adjacent existing semi-dry grassland fragments, which could potentially act as natural propagule donors.

We first sampled the sites in 2012, three years after they were established and mowing was initiated for the first time, and repeated our sampling in 2013. Our first aim was to test whether passive restoration can facilitate the establishment of target species. We assumed that passive colonisation was strong enough to initiate a recolonisation of target species at both restoration sites (Stampfli \& Zeiter 1999). Nevertheless, we expected differences between the two sites due to their former land use forms. Specifically, we hypothesised that the closed swards on the former orchard site would be an obstacle for target species (Donath et al. 2007). Our second aim was to analyse how abiotic site parameters and plant traits (Pywell et al. 2003, Fischer et al. 2013) affect early successional dynamics. Given that semi-dry grasslands occur on nutrient poor soils and often on welldrained slopes, we expected that colonisation success might depend on these abiotic site conditions. In addition, we assumed that colonisation success might depend on the distance to the reference site.

We addressed the following questions: 1) Does passive restoration facilitate the establishment of target species? 2) Do abiotic site conditions or nearest distance to adjacent semi-dry grasslands affect spatial patterns of target species establishment? 3) Can plant traits predict colonisation success among target species?

The results of our study will increase understanding of spontaneous colonisation processes in semi-dry grassland restoration. They will also reveal to what extent this rather cheap and easy method (Török et al. 2011, Kirmer et al. 2012) can be a viable option for future grassland restoration projects. In addition, identifying plant traits that predict colonisation success could help practitioners to distinguish between target species that are able to colonise restoration sites on their own and those that have to be transferred artificially (Clark et al. 2012). 


\section{METHODS}

\subsection{Study AREA}

Study sites were located in the SE Alpine foreland of Austria (Figure 1), in the vicinity of St. Anna am Aigen (AF: 46º $48^{\prime} 25.39^{\prime \prime} \mathrm{N} / 1^{\circ} 59^{\prime} 38.05^{\prime \prime}$ E 265$280 \mathrm{~m}$ a.s.l.; AO: $46^{\circ} 48^{\prime} 31.54^{\prime \prime} \mathrm{N} / 15^{\circ} 58^{\prime} 57.77^{\prime \prime E}$, 280-300 m a.s.l.). Soils are non-calcaric cambisols, stagnosols and calcaric leptosols (Anonymus 2012a). The region has a mild climate with an annual mean total precipitation of $831-841 \mathrm{~mm}$ and an annual mean temperature of $9.1-9.3^{\circ} \mathrm{C}(1971-$ 2000) (Anonymus 2012b). The potential natural vegetation in this area is thermophilic oak-hornbeam forest on deep nutrient-rich soils (specifically the association Galio sylvatici-Carpinetum Oberd. 1957) and acidophilic oak forest (specifically the association Genisto germanicae-Quercetum roboris Aich. 1933) (Willner 2007a, 2007b).

\subsection{INITIAL SITE CONDITIONS AND RESTORATION MEASURES}

Both restoration sites bordered directly on adjacent existing semi-dry grassland (Figure 2), which served as potential propagule donors for the project and as reference vegetation (REF). These existing dry grasslands belonged to the locally described association Cirsio pannonici-Brometum Steinbuch 1995 (nom. inv. according to Willner et al. 2013) but probably should be included into the Filipendulo vulgaris-Brometum Hundt \& Hübl ex Willner 2013 (Willner et al. 2013). The REF sites occupied 0.85 ha (near the former arable field site) and 0.68 ha (near the former apple orchard site). They had not been fertilised for at least 8 years before the onset of this study and had been managed by mowing and subsequent biomass removal (implemented mostly once a year but in some years twice, always after $15^{\text {th }}$ of June). Their soil was relatively acidic and nutrient poor with a moderate slope (see Table 1 for soil chemical parameters and slope). Median total species number was 44 vascular plants on $16 \mathrm{~m}^{2}$. The vegetation of the REF sites (Filipendulo vulgaris-Brometum) included Bromus erectus, Festuca rupicola, Cirsium pannonicum, Filipendula vulgaris, Thesium linophyllon and Euphorbia verrucosa. However, although the management of both reference sites was carried out regularly, we observed a slow change to more mesic and nutri-

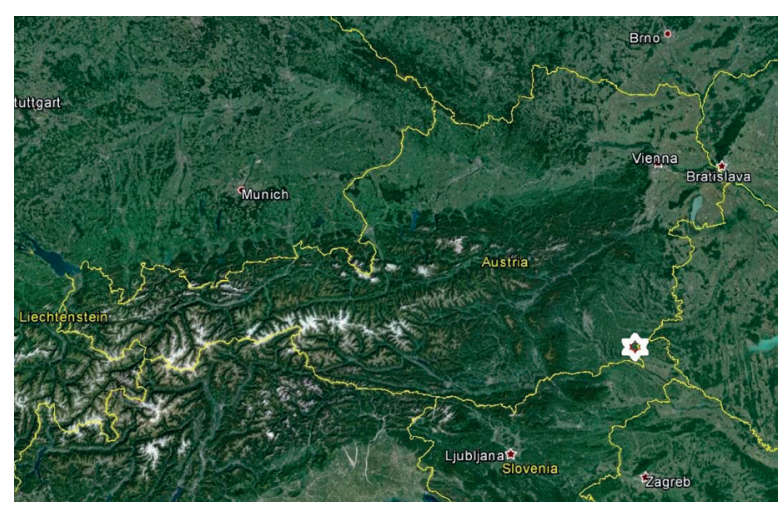

Figure 1: Study area in Sankt Anna am Aigen (SE of Austria), indicated by an unfilled star. $46^{\circ} 47^{\prime} 18^{\prime \prime} \mathrm{N}$ and $15^{\circ} 59^{\prime} 15.5^{\prime \prime} \mathrm{E}$. Google earth satellite image (ㄷ 2013 Google, Image Landsat; (c) 2009 GeoBasis-DE/BKG) accessed on October 10, 2013.

Slika 1: Raziskovano območje v Sankt Anna am Aigen (jugovzhodna Avstrija) označeno z zvezdo. 46 $47^{\prime} 18^{\prime \prime} \mathrm{N}$ and $15^{\circ} 59^{\prime} 15.5^{\prime \prime}$ E. Google earth satelitski posnetek (ㄷ 2013 Google, Image Landsat; (c) 2009 GeoBasis-DE/BKG) pridobljen 10. 10. 2013.

ent rich associations of the Arrhenatherion Koch 1926 in the course of our study. On a few baserich patches, we observed a change to the Ranunculo bolbosi-Arrhenatheretum Ellmauer 1993, but in our study area this usually meant increasing similarity to the Filipendulo vulgaris-Arrhenatheretum Hundt \& Hübl ex Ellmauer 1995.

Table 1: Abiotic site conditions at the semi-dry grassland reference sites (REF), the restored sites on the former arable field (AF) and apple orchard (AO). SD: standard deviation (mg/1000 g soil). P: plant available phosphorus (mg/1000 g), K: plant available potassium (mg/1000 g). Soil samples were collected in study plots in 2012. Values for the two reference sites were pooled. Tabela 1: Abiotski dejavniki rastišča na ciljnem polsuhem travišču (REF) in obnovljenih lokacijah na nekdanji obdelani površini (AF) in sadovnjaku jablan (AO). SD: standardni odklon (mg/1000 g soil). P: rastlinam dostopni fosfor (mg/1000 g), K: rastlinam dostopni kalij (mg/1000 g). Talne vzorce smo vzorčili na poskusnih ploskvah v letu 20121. Vrednosti za posamezni lokaciji smo združili.

\begin{tabular}{lllrrc}
\hline & & $\mathrm{pH}$ & $\mathrm{P}$ & $\mathrm{K}$ & Slope $\left(^{\circ}\right)$ \\
\hline REF & Mean & 4.9 & 17.9 & 102.3 & 8.6 \\
& SD & 0.2 & 2.5 & 58.7 & 6.5 \\
\hline AF & Mean & 4.8 & 28.4 & 190.7 & 4.4 \\
& SD & 0.3 & 8.3 & 44.6 & 1.9 \\
\hline AO & Mean & 5.3 & 15.0 & 119.4 & 8.7 \\
& SD & 0.1 & 1.6 & 18.4 & 3.4 \\
\hline
\end{tabular}


The former arable field (AF) was ploughed after the last year of crop production (2009). Since then, it has been mown (with subsequent biomass removal) once a year in late summer, without any additional measures of soil impoverishment and without application of plant propagule material. The size of the area was $1.2 \mathrm{ha}$, and $210 \mathrm{~m}$ of the perimeter bordered directly on the adjacent REF site. Abiotic site conditions were similar to the REF site in terms of $\mathrm{pH}$ but higher in phosphorus (P) and potassium (K). The slope at the AF was slightly shallower than at the REF (see Table 1 for soil-chemical parameters and slope).

The former apple orchard (AO) was abandoned in 2001, the area clear-cut and debris removed. The site was not ploughed. A regular mowing treatment (once per year in late summer with biomass removal) started in 2009. No plant propagule material was applied. The size of the area was 1.0 ha, with a $125 \mathrm{~m}$ border with the REF site. Abiotic site conditions were very similar to the REF site, but with a slightly higher $\mathrm{pH}$ (see Table 1 for soil-chemical parameters and slope).

\subsection{DATA COLLEGTION AND PREPARATION}

We sampled a total of 82 relevés $(\mathcal{N}=82$ samples $)$ of $16 \mathrm{~m}^{2}(4 \mathrm{~m} \times 4 \mathrm{~m})$ in 2012 and 2013, following the Braun-Blanquet (1964) approach. Plant nomenclature follows Fischer et al. (2008). In 2012, we studied 28 relevés at AF, 5 at the AF-reference site, 9 at $\mathrm{AO}$ and 3 at the AO-reference site (Fig- ure 2). Relevés at the REF sites were located $5 \mathrm{~m}$ from the border with the restored sites (Figure 2). Due to their similar floristic composition and structure, all REF sites were pooled in cases where $\mathrm{AF}$ and $\mathrm{AO}$ restoration sites were statistically analysed together. We resampled the AF and AO restored sites again in 2013 with the same sampling approach.

Relevés were chosen along four (AF) and three (AO) parallel transects, each running from the REF site to the restoration site (Figure 2). The distance between relevés was $10 \mathrm{~m}$ and between transects $20 \mathrm{~m}$. Each relevé was georeferenced and its distance to the nearest REF site boundary calculated in ArcGIS (ESRI 2012). We classified spatial distances into five classes $(1[0 \leq 10 \mathrm{~m}]$, $2[>10 \leq 20 \mathrm{~m}], 3[>20 \leq 30 \mathrm{~m}], 4[>30 \leq 40 \mathrm{~m}], 5[>40 \mathrm{~m}])$ following the formula suggested by Sturges (1926): $C=R /\left(1+3.322 \lg { }^{*} \mathcal{N}\right) ;(C=$ class width; $R=$ range; $\mathcal{N}=$ number of items).

Furthermore, we collected a 500-1000 g soil sample in the upper $10 \mathrm{~cm}$ mineral soil layer in each plot. The content of plant-available phosphorus $(\mathrm{P}: \mathrm{mg} / 1000 \mathrm{~g})$, potassium $(\mathrm{K}: \mathrm{mg} / 1000 \mathrm{~g}$ ) and $\mathrm{pH}$ in the soil was analysed by the "Landwirtschaftliches Versuchszentrum - Boden und Pflanzenanalytik", a department of the provincial government.

We used TURBOVEG (Hennekens \& Schamineé 2001) in order to store and manage our data and JUICE (Tichý 2002) to sort relevés and to calculate mean Ellenberg values (Ellenberg et al. 1991), Pielou evenness and the Frequency-

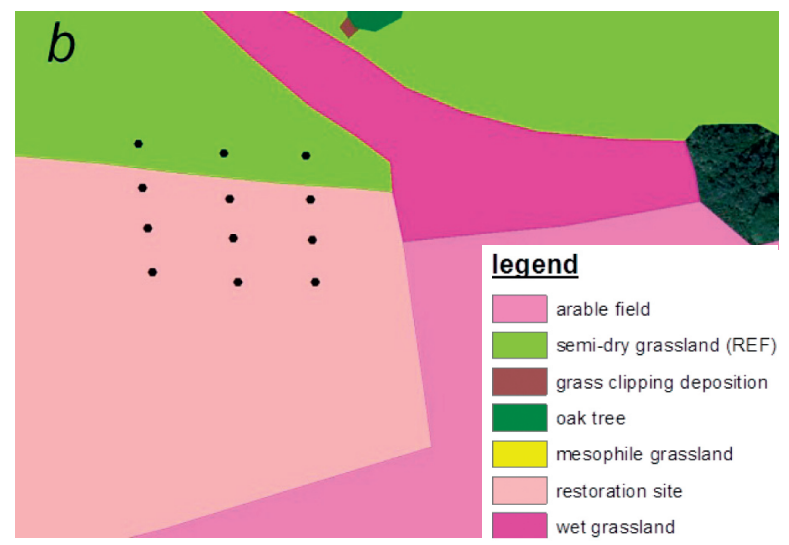

Figure 2: Layout of the sampling design at the former arable field site (AF) (a) and former apple orchard site (AO) (b). Black dots represent study plots. At each site, plots were arranged along parallel transects (four transects at AF, three at AO). Note that every transect started in the semi-dry grassland reference site (REF) and continued to the restoration site.

Slika 2: Postavitev vzorčnih ploskev na nekdanji obdelani površini (AF) (a) in nekdanjem sadovnjaku jablan (AO) (b). Črne točke predstavljajo vzorčne ploskve. Na vsaki lokaciji smo ploskve postavili v obliki vzporednih transektov (štirje transekti na AF in trije na AO). Vsak transekt se je začel v ciljnem polsuhem travišču (REF) in nadaljeval na obnovljeno rastišče. 
Positive-Fidelity Index (FPFI-values, Tichý 2005). Ellenberg values are expert-based indices that show species' realised preference along environmental gradients (Ellenberg et al. 1991). The indicator for soil fertility $(\mathrm{N})$ ranges from 1 (nutrient poor soils) to 9 (very nutrient rich soils). Evenness is an $\alpha$-diversity measure that accounts for species frequency or abundance (Dierschke 1994). The Frequency-Positive-Fidelity-Index (FPFI) is a similarity index that considers both frequency and fidelity of species and thus allows a comparison of single vegetation relevés to vegetation-units (Tichý 2005). We used it to calculate the similarity between relevés at restored sites and reference vegetation. The index ranges from 0 (low similarity) to 100 (high similarity). We decided to use the FPFI for our analysis because of its robustness regarding heterogeneity of data sets, which is usually the case in early stages of grassland restoration.

\subsection{ANALYSis OF THE COLONISATION PATTERNS OF TARGET SPECIES}

We estimated colonisation success by analysing FPFI, evenness, number of species and number of target species in comparison to the REF sites, and calculated how these indices changed be- tween 2012 and 2013 for each plot in the restored sites. Target species were defined as those occurring with a high percentage frequency (> $62.5 \%$, $\mathcal{N}=40$ ) at the REF sites. In total, the REF sites harboured 168 species, 40 of which were chosen as target species. We included taxa that mainly occur in the Arrhenatherion as target species because our goal was to understand colonisation mechanisms, unbiased by any phytosociological affiliations. For the analysis of plant traits, we included a larger pool of target species (species with a frequency $>37.5 \%$ at the REF, $\mathcal{N}=57$ ) in order to create a sufficiently large statistical sample size.

We classified species based on their colonisation success as a) successful colonisers (species with an absolute frequency $\geq 10$ in relevés at both restoration sites, in 2013; succs $\mathrm{AF}+\mathrm{AO}, \mathcal{N}=12$ ), b) successful colonisers in the arable field only (succs AF, $\mathcal{N}=9$ ), and c) unsuccessful colonisers (absolute frequency $\leq 2$ in relevés at both restoration sites in 2013; no succs, $\mathcal{N}=24$ ). For the statistical analysis of the ratio-scaled plant traits (Table 2), we merged the two groups of successful colonisers (succs $\mathrm{AF}+\mathrm{AO}$ and succs $\mathrm{AF}$ ) because they did not differ statistically in the traits correlated to restoration success (Ellenberg N, max. plant height, mowing tolerance; Mann-Whitney- $U$ test, $p>0.05$ ).

Table 2: List of plant traits included in the analysis. Tabela 2: Seznam rastlinskih znakov uporabljenih v analizi.

\begin{tabular}{|c|c|}
\hline Trait & Levels/units \\
\hline Mean maximum plant height (Klotz et al. 2002, Adler et al. 2008) & $\mathrm{Cm}$ \\
\hline Ellenberg values (Ellenberg et al. 1991) & $\mathrm{N}(1-9), \mathrm{F}(1-12)$ \\
\hline Dispersal type (Landolt 2010) & $\begin{array}{l}\text { At (anthropochory), Au (autochory), Dy (dysochory), En } \\
\text { (endozoochory), Ep (epichory), Me (meteochory, incl. } \\
\text { boleochory), My (myrmecochory) }\end{array}$ \\
\hline Vegetative propagation (Klotz et al. 2002, Landolt 2010) & $\begin{array}{l}\text { r (runner), nv (no vegetative propagation), gs (ground } \\
\text { shoots), rs (root shoots) }\end{array}$ \\
\hline Begin of flowering (Klotz et al. 2002) & Month \\
\hline End of flowering (Klotz et al. 2002) & Month \\
\hline Duration of flowering (Klotz et al. 2002) & Months \\
\hline Phenological group (Dierschke 1995, Klotz et al. 2002) & Ordinal scale \\
\hline Self sterility / self incompatibility (Klotz et al. 2002) & sc (self compatibility), si (self incompatibility) \\
\hline Pollination type (Klotz et al. 2002) & w (wind), in (insects), se (self), sn (snails) \\
\hline Mean seed weight (Klotz et al. 2002) & $\mathrm{Mg}$ \\
\hline Mean seed length (Klotz et al. 2002) & $\mathrm{Mm}$ \\
\hline Mean seed width (Klotz et al. 2002) & $\mathrm{Mm}$ \\
\hline Mean seed length/width (Klotz et al. 2002) & Ratio \\
\hline Strategy type (Klotz et al. 2002) & $\begin{array}{l}\text { C (competitors), CS (stress-tolerant competitors), CR } \\
\text { (competitive ruderals), SR (stress-tolerant ruderals), } \\
\text { CSR (intermediate strategists), R (ruderals) }\end{array}$ \\
\hline Mowing tolerance (Briemle et al. 2002, Klotz et al. 2002) & Ordinal (1-9) \\
\hline
\end{tabular}




\subsection{Tested Plant traits}

For each species, we extracted information on plant traits from the BIOLFLOR database (Klotz et al. 2002) and completed missing data from Fischer et al. (2008), Grime (1979) and Landolt (2010) (Table 2). For our analysis we chose 16 plant traits linked to species general migration and establishment ability (Table 2). Specifically, these traits reflected species competitiveness (e.g. plant height, ecological strategy), dispersal ability (e.g. seed weight, seed length, dispersal type), propagation (ability for vegetative propagation) and phenology (e.g. beginning and end of flowering, phenological group). Nominal traits (dispersal type, vegetative propagation type, selfincompatibility, pollination type, strategy type) were ratio-scaled by counting their proportion in the respective data group (REF sites, restoration sites, categories of success).

\subsection{Statistical ANALYSiS}

We calculated the Spearman-Rho coefficient to test for a correlation between abiotic parameters at restoration sites (slope, soil $\mathrm{pH}, \mathrm{P}, \mathrm{K}$ and distance to REF sites) and restoration success (number of species, number of target species, evenness, FPFI). The same approach was used to calculate a correlation between plant traits and establishment success of target species at restoration sites. In addition, we calculated community indices for each plot [cover in \%, number of species, number of target species, similarity to reference sites (FPFI), evenness, Ellenberg $\mathrm{N}$ and F]. These were described using the median value, to avoid problems with skewing caused by outliers. Furthermore, we used the Mann-Whitney- $U$ test to assess differences in community indices between the REF and restoration sites and to compare changes in community indices between 2012 and 2013.

To provide information about the main ecological strategy of successful and unsuccessful species, we created a triangular ordination plot based on Grime (1979). Each species in the respective group (no succs, succs $\mathrm{AF}+\mathrm{A} 0$ and succs $\mathrm{AF}$ ) was counted without weighing for frequency. Each strategy component (C, S or R) was given a single value, with all values summing up to 100 . For example, a CR-strategist would be characterised by the following vectors: $\mathrm{C}=50, \mathrm{R}=50, \mathrm{~S}=0$.
For the group (no succs, succs $\mathrm{AF}+\mathrm{A} 0$ and succs AF), each strategy component was averaged. The respective group was then plotted in the triangular diagram.

We performed all statistical analyses in SPSS Statistics 21 (IBM 2012).

\section{RESULTS}

\subsection{General trends in the 2012-2013 PERIOD}

In 2013, total vegetation cover increased significantly at the AF site but not at the $\mathrm{AO}$ site (Figure 3a). At the AF site, median total cover in 2013 was already similar to the median cover at the adjacent REF site (Figure $3 \mathrm{a}$ ). We did not detect any significant changes in evenness at either restoration site between 2012 and 2013. However, evenness showed a lower median and a higher variance in the restoration sites compared to the REF sites (Figure 3b).

At both restoration sites, total species number significantly increased from 2012 to 2013 (Figure 4a) but was still lower in AO than in AF. In 2013, seven species appeared for the first time at the restoration sites, in some cases with surprisingly high frequencies and high cover values. In order of decreasing frequency, these were: Anthoxanthum odoratum, Avenula pubescens, Dianthus carthusianorum, Euphorbia verrucosa, Thesium linophyllon, Filipendula vulgaris, Pimpinella saxifraga.

The number of target species per plot significantly increased at the AF site but not at the AO site (Figure $4 \mathrm{~b}$ ). In terms of the floristic similarity, the FPFI in AF plots increased significantly from 2012 to 2013, but not in AO plots (Figure 4c). However, mean FPFI in AF plots (median 28) still strongly differed from median values at its REF site (median 68.7).

Plots at restoration sites had higher median Ellenberg values for moisture (F) and nitrogen (N) than plots at REF sites. Mean Ellenberg F values did not significantly change from 2012 to 2013 at either restoration site. However, mean Ellenberg $\mathrm{N}$ values increased significantly at the AF site (Figure 4d).

In comparison to the REF sites, both the AO and $\mathrm{AF}$ site showed a larger number of $\mathrm{C}$ and a lower number of CSR species. Both sites were characterised by high proportions of ruderals and CR species. Interestingly, the proportion of 

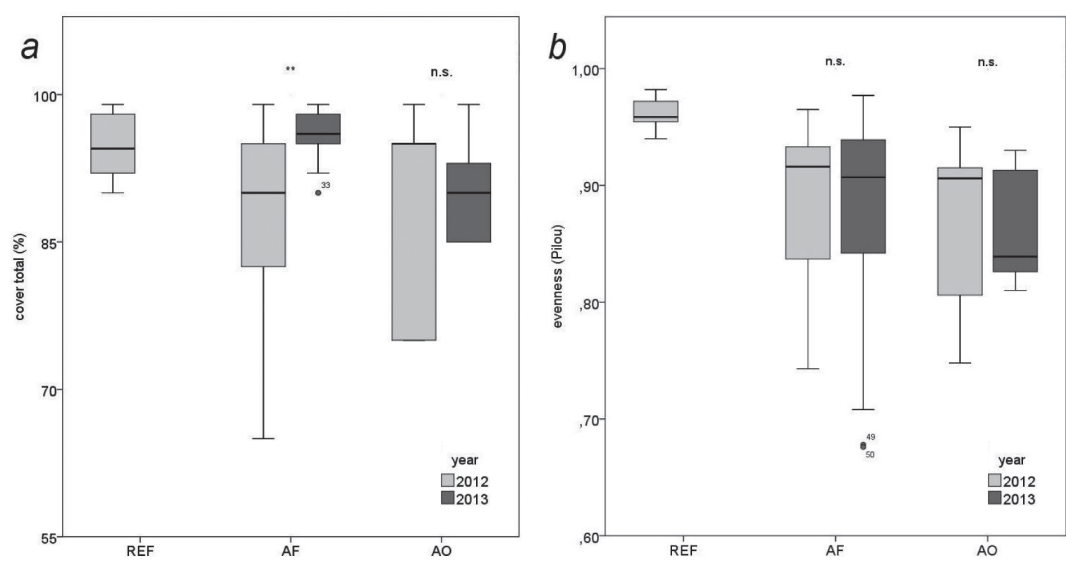

Figure 3: Changes in total cover (a) and evenness (b) from 2012 to 2013 at the former-arable field $(\mathrm{AF})$ and former apple-orchard (AO) restoration sites. For each restoration site, we compared changes between the two years for both parameters by using Mann-Whitney- $U$ tests (as indicated by asterisks or 'n.s.'). In addition, we also compared parameters at the reference sites (REF) and at the restored sites (AF and AO) of both years by using pairwise Mann-Whitney- $U$ tests. Total cover values at AF and AO did not differ significantly from REF in both years $(p>0.05)$. Evenness at $\mathrm{AO}$ and AF did differ significantly from $\operatorname{REF}\left(p \leq 0.05\right.$ level). n.s.: not significant $(p>0.05)$, ${ }^{*} 0.01<p \leq 0.05,{ }^{* *}: p \leq 0.01$.

Slika 3: Spremembe skupne pokrovnosti (a) in izenačenosti (b) od 2012 do 2013 na obnovljenih lokacijah na nekdanji obdelani površini (AF) in nekdanjem sadovnjaku jablan (AO). Za vsako lokacijo smo primerjali spremembe med obema letoma za oba dejavnika z Mann-Whitney-evim- $U$ testom (označeno z zvezdico ali n.s.). Dodatno smo primerjali dejavnike ciljnega rastišča $(\mathrm{REF})$ in obeh obnovljenih površin (AF in $\mathrm{AO}$ ) za obe leti z uporabo parnega Mann-Whitney-evega- $U$ testa. Skupne pokrovne vrednosti $\mathrm{AF}$ in $\mathrm{AO}$ se niso statistično razlikovale od REF $\mathrm{v}$ obeh letih $(p>0,05)$. Izenačenost $\mathrm{AF}$ in $\mathrm{AO}$ se ni statistično razlikovala od REF v obeh letih $(p>0,05)$. n.s.: ni statistično značilno $(p>0,05),{ }^{*}: 0,01<p \leq 0,05,{ }^{*}: p \leq 0,01$.
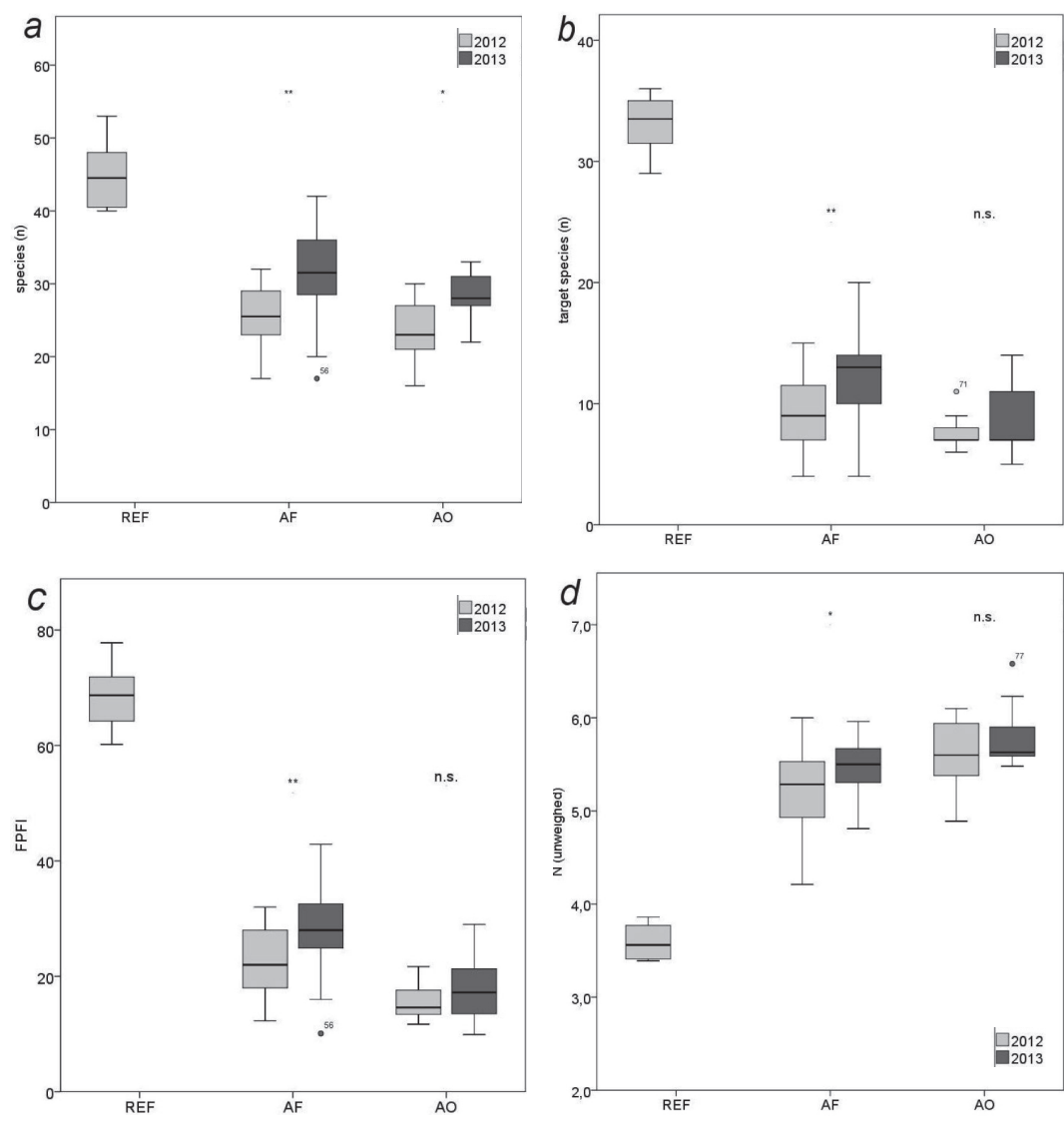

lokacijami (v obeh letih) z parnim Mann-Whitney-evim- $U$ testom. V tem primeru so se obnovljene površine statistično značilno razlikovale $\mathrm{v} v$ seh parametrih in $\mathrm{v}$ obeh letih $(p<0,05)$. n.s.: ni statistično značilno $(p>0,05),{ }^{*}: 0,01<p \leq 0,05,{ }^{* *}: p \leq 0,01$.
Figure 4: Changes in (a) total number of species, (b) number of target species, (c) FPFI to reference sites (REF) and (d) Ellenberg $\mathrm{N}$ values at the former arable field (AF) and apple orchard (AO) restoration sites from 2012 and 2013. For each restoration site, we compared changes in each parameter between the two years by using MannWhitney- $U$ tests (as indicated by asterisks or 'n.s.). In addition, we also compared parameters at the reference sites (REF) and at the restored sites (in both years) by using pairwise MannWhitney- $U$ tests. In this case, restored sites and reference sites significantly differed in all parameters, and in both years $(p<0.05)$. n.s.: not significant $(p$ $>0.05),{ }^{*}: 0.01<p \leq 0.05,{ }^{* *}: p \leq 0.01$.

Slika 4: Spremembe (a) skupnega števila vrst, (b) števila ciljnih vrst, (c) FPFI do ciljne površine (REF) in (d) Ellenbergovih $\mathrm{N}$ vrednosti na nekdanji obdelani površini (AF) in sadovnjaku jablan (AO) med letoma 2012 in 2013. Za vsako obnovljeno lokacijo smo primerjali spremembe vsakega dejavnika med obema letoma z Mann-Whitney-evim- $U$ testom (označeno z zvezdico ali z 'n.s.). Dodatno smo primerjali dejavnike med ciljno površino (REF) in obnovljenimi 

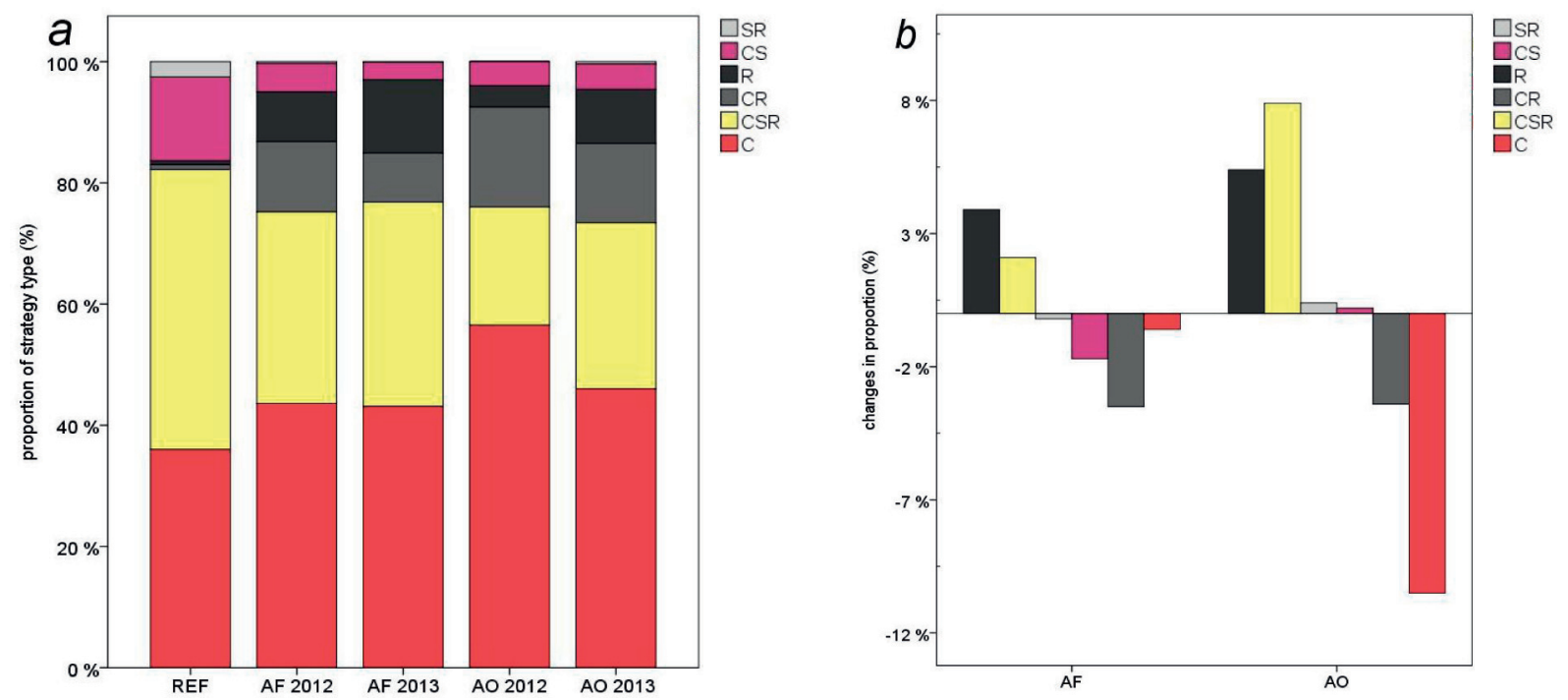

Figure 5: Proportion of Grime's strategy types at the reference and restored sites in 2012 and 2013 (a). Proportional changes in ecological strategy types at the two restoration sites from 2012 to 2013 (b). SR: stress-tolerant ruderals, CS: stress-tolerant competitors, R: ruderals, CR: competitive ruderals, CSR: intermediate strategists, C: competitors, REF: semi-dry grassland reference sites, AF: arable field restoration site, AO: apple orchard restoration site.

Slika 5: Delež tipov strategij po Grimu na ciljni in obnovljenih površinah v letih 2012 in 2013. (a). Spremembe deležev ekoloških strategij na obeh obnovljenih površinah v letih 2012 in 2013 (b). SR: stres tolerantne ruderalne vrste, CS: stres tolerantni kompetitorji, R: ruderalke, CR: kompetitivne ruderalke, CSR: vrste z vmesno startegijo, C: kompetitorji, REF: polsuho travišče-ciljna površina, AF: obnovljena obdelana površina, AO: obnovljena površina na nekdanjem sadovnjaku jablan.

Table 3: Spearman-Rho correlation matrix among abiotic parameters and indices for restoration success [number of species: species $(n)$, number of target species: target species $(n)$, evenness, Frequency-Positive-Fidelity-Index (FPFI), Distance: distance between plots and nearest border with reference site (REF)]. Indices for restoration success from 2012 and 2013 were pooled. Abiotic parameters were measured in 2012. Significant correlations are indicated with asterisks: ${ }^{*}: 0.01<p \leq 0.05,{ }^{* *}: p \leq 0.01$.

Tabela 3: Spearman-Rho korelacijska matrika med abiotskimi dejavniki in indikatorji uspeha obnovitve [število vrst: species $(n)$, število tarčnih vrst: target species $(n)$, izenačenost: evenness, Frequency-Positive-Fidelity-Index (FPFI), oddaljenost: distance between plots and nearest border with reference site (REF)]. Indikatorje uspešnosti obnove v letih 2012 in 2013 smo združili. Abiotske dejavnike smo vzorčili leta 2012. Statistično značilne korelacije so označene z zvezdico: ${ }^{*}: 0.01<p \leq 0.05,{ }^{* *}$ : $p \leq 0.01$.

\begin{tabular}{|c|c|c|c|c|c|c|}
\hline \multirow{2}{*}{\multicolumn{7}{|c|}{ Arable field restoration site (AF. $N=56)$}} \\
\hline & & & & & & \\
\hline \multirow{2}{*}{ Species $(n)$} & Spearman-Rho & -.063 & -.231 & .090 & -.098 & $-.406^{* *}$ \\
\hline & $P$ & .643 & .087 & .510 & .472 & .002 \\
\hline \multirow{2}{*}{ Target species $(n)$} & Spearman-Rho & -.031 & -.179 & .044 & -.154 & $-.464^{* *}$ \\
\hline & $P$ & .819 & .187 & .745 & .258 & .000 \\
\hline \multirow{2}{*}{ Evenness } & Spearman-Rho & -.109 & -.188 & -.025 & -.144 & $-.364^{* *}$ \\
\hline & $P$ & .424 & .165 & .853 & .291 & .006 \\
\hline \multirow{2}{*}{ FPFI } & Spearman-Rho & -.059 & -.218 & .101 & -.095 & $-.513^{* *}$ \\
\hline & $P$ & .665 & .107 & .458 & .487 & .000 \\
\hline \multicolumn{7}{|c|}{ Apple orchard restoration site (AO. $N=18)$} \\
\hline \multirow{2}{*}{ Species $(n)$} & Spearman-Rho & .320 & .096 & .134 & -.049 & .021 \\
\hline & $P$ & .196 & .705 & .596 & .846 & .935 \\
\hline \multirow{2}{*}{ Target species $(n)$} & Spearman-Rho & $.644^{* *}$ & -.383 & .376 & .239 & $-.496^{*}$ \\
\hline & $P$ & .004 & .116 & .124 & .340 & .036 \\
\hline \multirow{2}{*}{ Evenness } & Spearman-Rho & .139 & -.222 & .325 & .191 & -.071 \\
\hline & $P$ & .583 & .376 & .189 & .449 & .781 \\
\hline \multirow{2}{*}{ FPFI } & Spearman-Rho & $.525^{*}$ & -.175 & .258 & .263 & -.305 \\
\hline & $P$ & .025 & .487 & .301 & .293 & .218 \\
\hline
\end{tabular}


ruderals increased from 2012 to 2013 at both restoration sites, whereas the proportion of competitors decreased strongly at the AO site (Figure 5). In addition there was a higher turnover rate of strategy types in the AO.

\subsection{Spatial Golonisation Patterns}

We did not find any significant correlation between measured abiotic soil conditions and colonisation success at either site. However, colonisation success at the AF site was significantly correlated with distance to REF (Table 3). At the AO site, community indices did not show a significant correlation with distance, except for the number of target species, which was negatively correlated to distance and positively to slope (Table 3).

At the AF site, all community indices were much lower than in the REF sites in all distance classes (Figure 6a-c), except for evenness in distance class 5 (Figure 6d). In 2013, the AF site showed a significant increase in the number of target species, total species number, and similarity (FPFI) between the first and second distance classes (Figure 6). For distance classes 3 and 5, we also observed a higher variance in the total species number. The same was true for the changes of the evenness index, where an increasing variance was detectable in all distance classes except class 4.
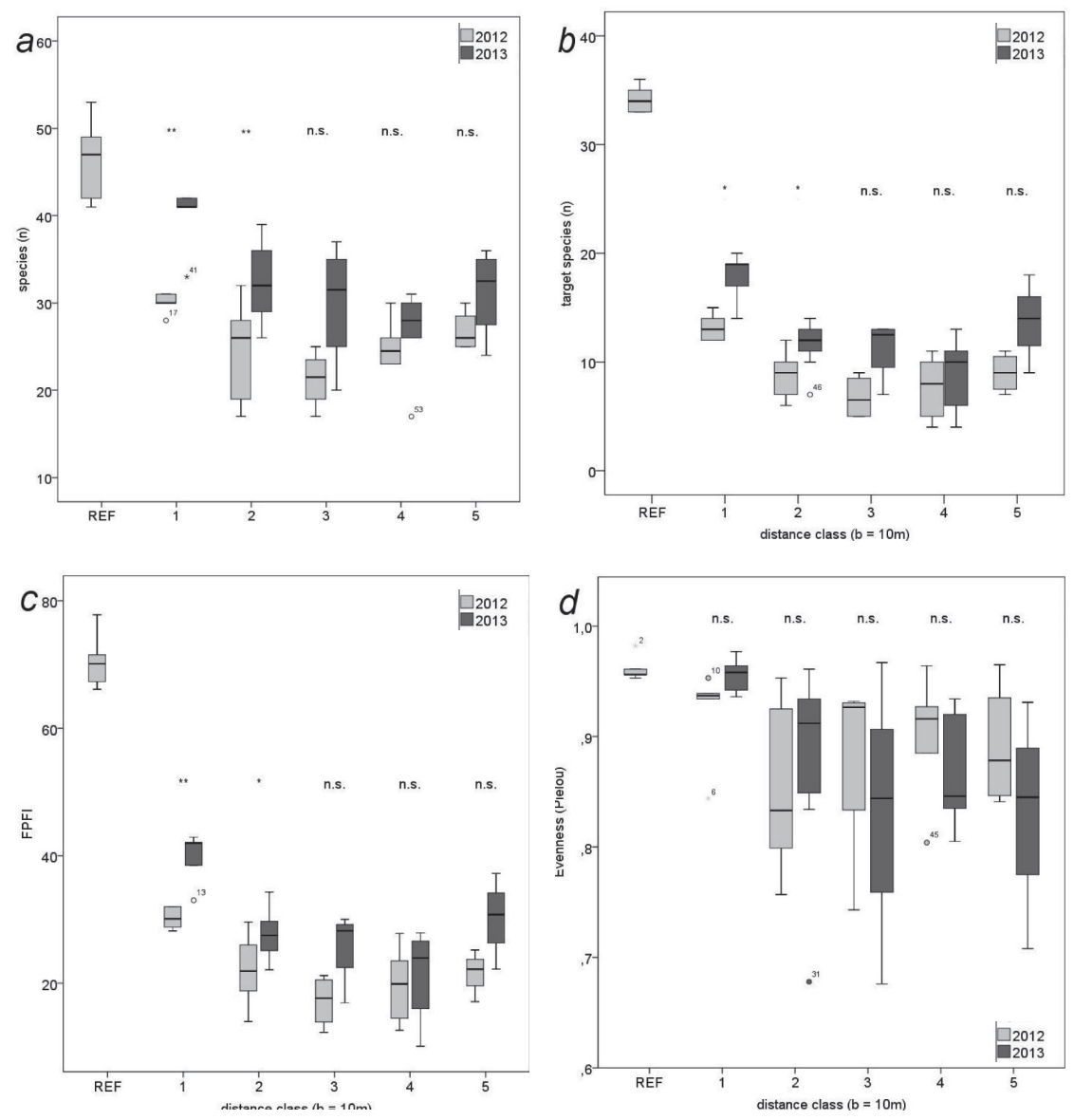

Figure 6: Changes in species number (a), number of target species (b), similarity (FPFI) to reference sites (c) and evenness (d) along five distance classes (class width $=10 \mathrm{~m}$ ) at the fomer arable field site, from 2012 to 2013. For each parameter and distance class, we compared changes between the two years by using MannWhitney- $U$ tests (as indicated by asterisks or 'n.s.'). In addition, we also compared parameters at the AF reference sites (REF) and at the restored sites (at all distance classes and years) by using pairwise Mann-Whitney- $U$ tests. In this case, restored sites and reference sites significantly differed in all parameters, across all distance classes and years $(p<0.05)$. The only exception was evenness, which did not show a significant difference between reference site and distance classes 1(2013), 3(2013), and 5(2012) at restored sites $(\mathrm{p} \leq 0.05)$. n.s.: not significant $(p>0.05),{ }^{*}: 0.01<p \leq 0.05$, ${ }^{* *}: p \leq 0.01$.

Slika 6: Spremembe v številu vrst (a), številu ciljnih vrst (b), podobnosti (FPFI) do ciljne površine (c) in izenačenosti (d) med petimi razredi oddaljenosti (širina razreda $=10 \mathrm{~m}$ ) na nekdanji obdelovani površini med letoma 2012 in 2013 . Spremembe smo primerjali za vsak dejavnik in razred oddaljenosti z z Mann-Whitney-evim- $U$ testom (označeno z zvezdico ali z ' $n$.s.'). V tem primeru se obnovljene in primerjalna površina statistično značilno razlikujejo v vseh dejavnikih v vseh razredih oddaljenosti in letih $(p<0,05)$. Edina izjema je izenačenost, ki se ne razlikuje med ciljno površino in razredih oddaljenosti 1(2013), 3(2013) in $5(2012)$ na obnovljenih površinah $(p \leq 0,05)$. n.s.: not significant $(p>0,05),{ }^{*}: 0,01<p \leq 0,05,{ }^{* *}: p \leq 0,01$. 


\subsection{Plant traits}

Our analysis showed that successful colonisers were characterised by strong competitive ability, i.e. a mean maximum plant height of $>60 \mathrm{~cm}$, an Ellenberg $\mathrm{N}$ value of $>5$, and a mowing tolerance of $>6$ (Table 4, Figure 7a). Traits related to phenology (beginning, end, duration of flowering; phenological group) and seeds (weight, length, width, length-width ratio) were not linked to colonisation success (Table 4).

Table 4: Spearman-Rho correlation among plant traits (ratio scaled) and absolute frequency of target species that colonised restoration sites. Significant correlations are indicated with asterisks: ${ }^{*}: 0.01<p \leq 0.05 ;^{* *}: p \leq 0.01$. Tabela 4: Spearman-Rho korelacijska matrika med rastlinskimi znaki (v odstotkih) in absolutno frekvenco ciljnih vrst, ki se naseljujejo na obnovljene površine. Statistično značilne korelacije so označene $\mathrm{z}$ zvezdico: ${ }^{*}: 0.01<\mathrm{p} \leq 0.05{ }^{* *}: \mathrm{p} \leq 0.01$.

\begin{tabular}{|c|c|c|}
\hline Plant trait & & $\begin{array}{l}\text { Absolute frequency in restora- } \\
\text { tion sites (2012 and 2013) }\end{array}$ \\
\hline Max. plant & Spearman-Rho & $.515^{* *}$ \\
\hline \multirow[t]{2}{*}{ height } & $P$ & .000 \\
\hline & $N$ & 57 \\
\hline \multirow{3}{*}{$\begin{array}{l}\text { Ellenberg } \mathrm{N} \\
\text { value }\end{array}$} & Spearman-Rho & $.597^{* *}$ \\
\hline & $P$ & .000 \\
\hline & $N$ & 43 \\
\hline \multirow{3}{*}{$\begin{array}{l}\text { Phenological } \\
\text { group }\end{array}$} & Spearman-Rho & .147 \\
\hline & $P$ & .275 \\
\hline & $N$ & 57 \\
\hline \multirow{3}{*}{$\begin{array}{l}\text { Begin of } \\
\text { flowering }\end{array}$} & Spearman-Rho & .018 \\
\hline & $P$ & .896 \\
\hline & $N$ & 57 \\
\hline \multirow{3}{*}{$\begin{array}{l}\text { End of } \\
\text { flowering }\end{array}$} & Spearman-Rho & .174 \\
\hline & $P$ & .194 \\
\hline & $N$ & 57 \\
\hline \multirow{3}{*}{$\begin{array}{l}\text { Duration of } \\
\text { flowering }\end{array}$} & Spearman-Rho & .242 \\
\hline & $P$ & .070 \\
\hline & $N$ & 57 \\
\hline \multirow[t]{3}{*}{ Seed weight } & Spearman-Rho & -.123 \\
\hline & $P$ & .380 \\
\hline & $N$ & 53 \\
\hline \multirow[t]{3}{*}{ Seed length } & Spearman-Rho & .136 \\
\hline & $P$ & .323 \\
\hline & $N$ & 55 \\
\hline \multirow[t]{3}{*}{ Seed width } & Spearman-Rho & -.204 \\
\hline & $P$ & .142 \\
\hline & $N$ & 53 \\
\hline \multirow{3}{*}{$\begin{array}{l}\text { Seed length/ } \\
\text { width ratio }\end{array}$} & Spearman-Rho & .268 \\
\hline & $P$ & .052 \\
\hline & $N$ & 53 \\
\hline \multirow{3}{*}{$\begin{array}{l}\text { Mowing } \\
\text { tolerance }\end{array}$} & Spearman-Rho & $.534^{* *}$ \\
\hline & $P$ & .000 \\
\hline & $N$ & 57 \\
\hline
\end{tabular}

In the triangle plot of ecological strategy, species that successfully colonised both sites had higher C-values than those that successful colonised only the AF site. Compared to these groups, unsuccessful colonisers exhibited $\mathrm{R}$ and $\mathrm{S}$ values that were nearly twice as high and had much lower $\mathrm{C}$ values (Figure $7 \mathrm{~b}$ ).

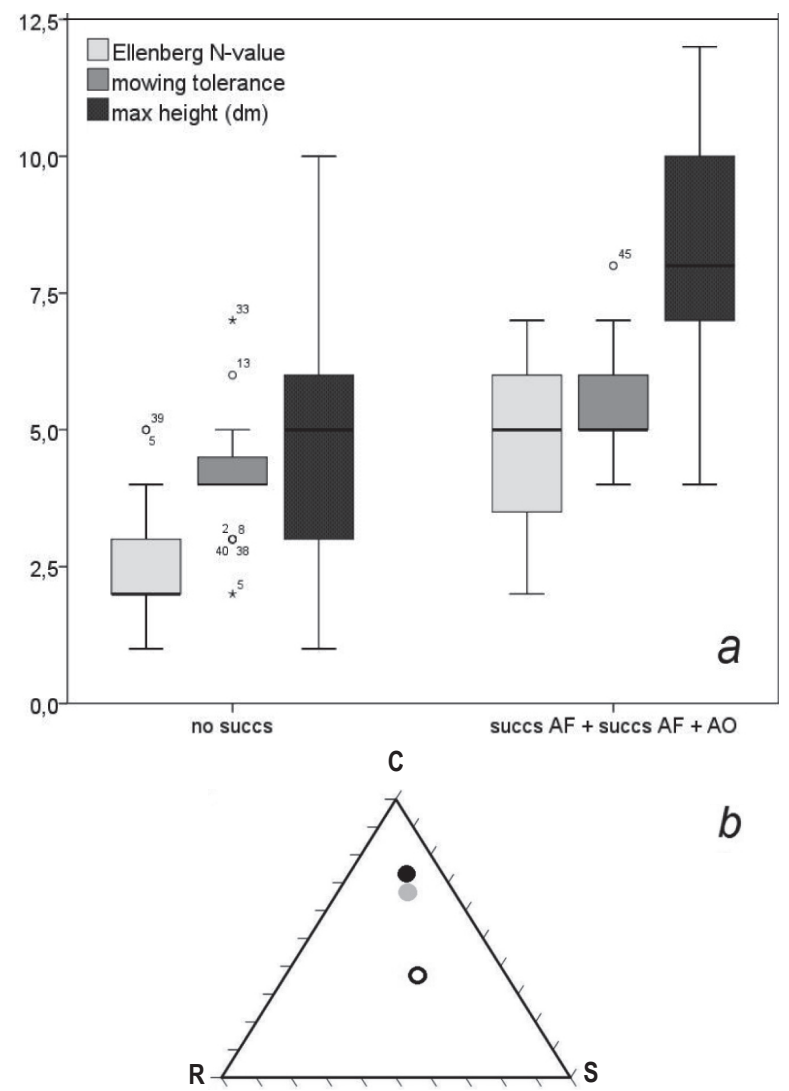

Figure 7: Distribution of plant traits among species that successfully colonised restoration sites (succs AF + succs AF + $\mathrm{AO}$ ) and those who failed to do so (no succs) (a). The successful and unsuccessful group differed significantly in their mean trait values: Ellenberg N, mowing tolerance, max height (Mann-Whitney- $U$ test, $p \leq 0.001$ ). Strategy triangle plot (b) of species groups (black dot: succs $\mathrm{AF}+\mathrm{AO}$, grey dot: succs $\mathrm{AF}$, black ring: no succs). no succs: unsuccessful colonisers, succs $\mathrm{AF}+$ succs AF+AO: successful colonisers of the arable field and of the apple orchard, C: competition, R: disturbance, S: stress. Slika 7: Porazdelitev rastlinskih znakov med vrstami, ki so se uspešno naselile na obnovljene površine(succs AF + succs $\mathrm{AF}+\mathrm{AO}$ ) in tistimi, ki so bile pri tem neuspešne (no succs) (a). Uspešne in neuspešne skupine se statistično značilno razlikujejo v povprečnih vrednostih znakov: Ellenbergova $\mathrm{N}$ vrednost, odpornost na košnjo, največja višina (Mann-Whitney- $U$ test, $p \leq 0,001)$. Trikotni graf strategij skupin vrst (b) (črne točke: succs $\mathrm{AF}+\mathrm{AO}$, sive točke: succs $\mathrm{AF}$, črni krožci: no succs). no succs: neuspešni kolonizatorji, succs AF + succs AF+AO: uspešni kolonizatorji na obdelanih tleh in sadovnjaku jablan, C: kompeticija, R: motnja, S: stres. 
We did not find a significant correlation between colonisation success and dispersal type, but unsuccessful species were more likely to be myrmecochorous (Figure 8a). Species that were able to colonise both restoration sites were more likely to be wind-pollinated (Figure $8 \mathrm{~b}$ ), while successful colonisers at the AF site had more
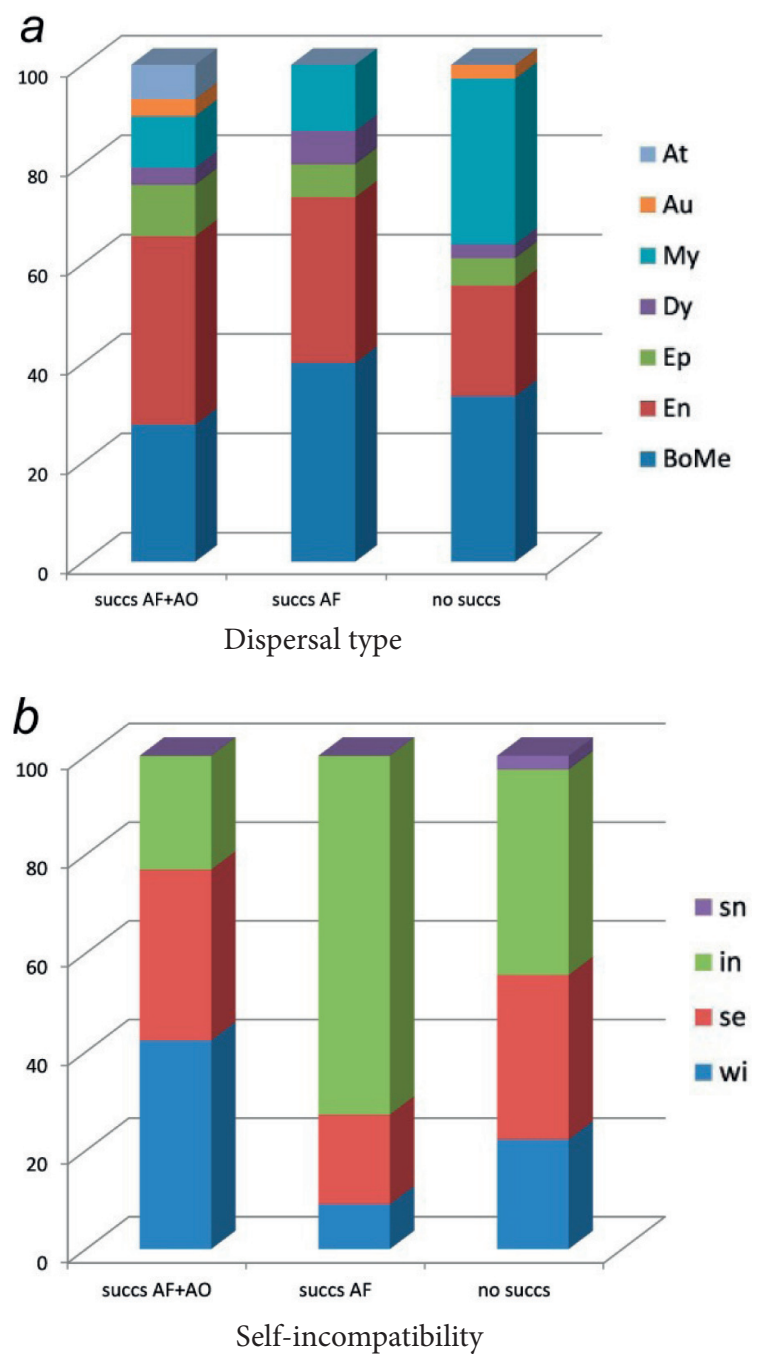

insect-pollinated species. More than half of the successful species at the $\mathrm{AF}+\mathrm{AO}$ sites were selfincompatible. However, the opposite was true for successful species at the AF site and for unsuccessful species (Figure 8c). Successful species were more likely to have runners and rhizomes than unsuccessful species (Figure 8d).
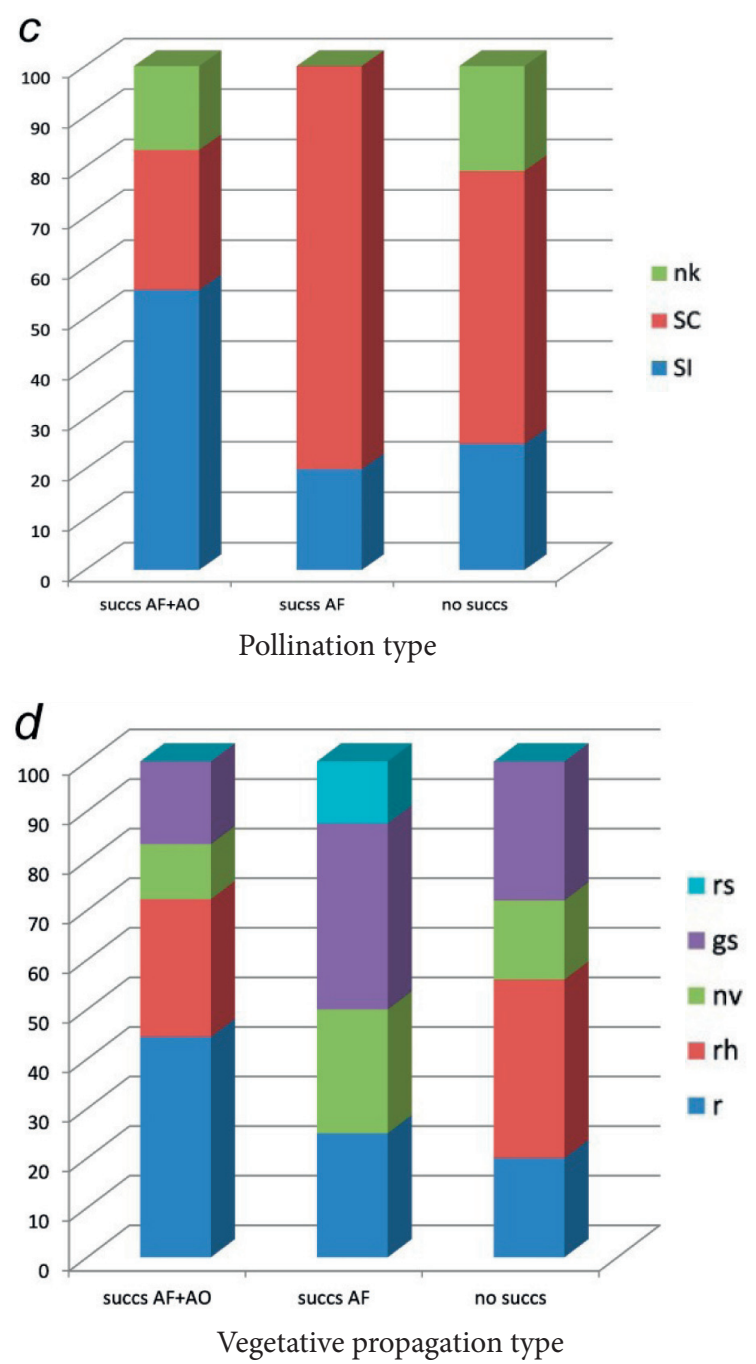

Figure 8: Distribution of plant traits among species that successfully colonised the former arable field and apple orchard restoration site (succs $\mathrm{AF}+\mathrm{AO}$ ) and former arable field site (succs $\mathrm{AF}$ ) and those who failed to do so (no succs). When species shows two or more attributes for a trait, we counted each of them separately (i.e. 100\% is the sum of all entries). Dispersal types: At: anthropogenic, Au: autochory, My: myrmecochory, Dy: dystochory, Ep: epizoochory, En: endozoochory, BoMe (anemochory: meteochory + boleochory); pollination types: sn: snails, in: insects, se: self, wi: wind; self incompatibility: nk: not known, SC: self compatible, SI: self incompatible; vegetative propagation types: rs: root shoots, gs: ground shoots, nv: no vegetative propagation, rh: rhizomes, r: runners.

Slika 8: Porazdelitev rastlinskih znakov med vrstami, ki so se uspešno naselile na obnovljeno nekdanjo obdelano površino in sadovnjak jablan (succs AF $+\mathrm{AO}$ ) in nekdanjo obdelano površino (succs $\mathrm{AF}$ ) in tistimi, ki so bile neuspešne (no succs). Če ima vrsta več vrednosti za isti znak smo jih upoštevali ločeno (t.j. skupni delež je 100\%). Načini razširjanja: At: antropogeni, Au: avtohorija, My: mirmekohorija, Dy: distohorija, Ep: epizoohorija, En: endozoohorija, BoMe (anemohorija: meteohorija + boleohorija); načini opraševanja: sn: polži, in: žuželke, se: samooprašitev, wi: veter; samoinkompatibilne: nk: neznano, SC: samokompatibilen, SI: samoinkompatibilen; nespolno razmnoževanje: rs: koreninski poganjki, gs: pritalni poganjki, nv: brez vegetativnega razmnoževanja, rh: rizomi, r: pritlike. 


\section{DISCUSSION}

\subsection{General trends}

Our results show that, four years after project initiation, the vegetation cover at the restored sites was high but many target species were still absent or underrepresented. Instead, the vegetation was dominated by species typical for the more mesic and species-poor Arrhenatherion or thermophilic ruderal associations. An increase in community indices (target species numbers, evenness, FPFI) was observed only at short distances from the REF sites. It is only here that seven target species appeared for the first time in 2013.

\subsection{Spatial GOlONisation PATterns}

Contrary to our expectations, soil chemical variables did not show any correlation with colonisation success. For the AO site, this result is not surprising because soil nutrient content was similar to the reference site. At the AF site, soil $\mathrm{K}$ was higher and $\mathrm{P}$ slightly higher. However, neither of these variables explained colonisation success. The differences in nutrient content must have been too small to affect the early colonisation process. Occurrence patterns of single species did also not reveal any evidence that soil nutrients were driving early colonisation. Species known to avoid soils with high phosphorus content were among the successful (Anthoxanthum odoratum, Leucanthemum vulgare, Plantago lanceolata, Avenula pubescens and Hypochaeris radicata), and unsuccessful colonisers (Potentilla erecta, Betonica officinalis, Briza media, Linum catharticum and Polygala vulgaris) (Hejcman et al. 2007).

At the AF site, spatial distance to the REF site was the only variable to significantly correlate with colonisation success (indicated by the number of target species and FPFI). In total, our target plants reached up to $20 \mathrm{~m}$ in four years. This corresponds to a study by Stampfli \& Zeiter (1999) who found a maximum migration distance of 5-25 $\mathrm{m}$ in 10 years, in spontaneously colonised montane grassland, in Switzerland.

Interestingly, the $\mathrm{AO}$ site showed a much smaller increase in target species than the AF site and lacked distinct colonisation patterns. This can be explained by the fact that it had a continuous closed sward at the beginning of the restora- tion and was not ploughed (Donath et al. 2007). Consequently, it lacked the necessary "colonisation window" (Bartha et al. 2003) for the establishment of target species. This result also implies that the dense vegetation cover at both restoration sites could be a further obstacle for the establishment of target species in the coming years.

\subsection{Role OF PLANT TRAits}

Our analysis of ecological strategy types shows that the small and stress-adapted CSR, CS and SR species of the Bromion were underrepresented in the $\mathrm{AF}$ and even rarer in $\mathrm{AO}$ compared to the REF. This is in line with Pywell et al. (2003), who described this trend as a general phenomenon in grassland restoration. The strong decline of competitive (C) species from 2012 to 2013 at the AO site can be explained by a decrease in shrub species, which responded negatively to the annual mowing regime. In general, species that were able to successfully colonise restored sites had traits linked to competitive ability: they were tall, had a preference for nutrient rich soil (high Ellenberg $\mathrm{N}$-values) and had a high mowing tolerance. In fact, we found competitive species to dominate early succession stages even in plots adjacent to semi-dry grasslands, where the soil had not been enriched with nutrients. In any case, soil nutrient content at restorated sites was not particularly high (with the exception of $\mathrm{K}$ in $\mathrm{AF}$ ) and was (in most plots) below the known upper limit for species-rich grasslands (Janssens et al. 1998).

In general, competitive grassland species have become more frequent within Festuco - Brometea associations since the $1950 \mathrm{~s}$, due to abandonment, fragmentation and intensification of dry grasslands (Hansson \& Fogelfors 2000, Kahmen et al. 2002, Dostálek \& Frantík 2008, Pipenbaher et al. 2013). Competitors were also found to dominate the colonisation process in urban grassland restoration (Fischer et al. 2013) and anthropogenic habitats on bare soil (Prach \& Pyšek 1999). Furthermore there is evidence that in Central Europe, remnants of semi-dry grassland sites in rather humid climate regions are more dependent on historical management with over-exploitation and nutrient depletion than in arid regions. Such anthropogenic nutrient removal is necessary to provide stress-adapted small species with a competitive advantage (Hansson \& Fogelfors 2000). The lack of appropriate management could lead 
to litter accumulation, nutrient accumulation and reduction of light availability (Ruprecht \& Szabó 2012). This trend in turn would favour the colonisation of typical Arrhenatherion species and be an obstacle for small species. There is evidence that even successfully restored grasslands transform into more productive stands with undesired species if management intensity is too low (Lawson et al. 2004, Kelemen et al. 2014).

Species with a low plant height had a low colonisation success in our study. This is in line with Lauterbach et al. (2013), who explained the rarity of species on a local scale by their low plant height. They refer to the interesting observation that plant height is much more important for effective seed dispersal (within different dispersal types) than low seed weight (Thomson et al. 2011). In our study, we found that neither seed traits nor dispersal type were good predictors of colonisation success. Practitioners could address this problem and accelerate colonisation by introducing grazing, which could act as a dispersal vector and could generate germination microsites (Jacquemyn et al. 2011).

The fact that neither phenological traits nor seed characteristics explained spontaneous colonisation ability at a local scale supports the findings of previous studies (Eriksson \& Jakobsson 1998, Moles \& Westoby 2004, Römermann et al. 2007).

In our study, successful colonisers were more likely to be self-incompatible and anemophilous than unsuccessful species. Self-incompatible species show a higher genetic diversity than their selfcompatible relatives (Igic et al. 2008). This could promote their competitive ability and hence colonisation success. On the other hand, small populations have often developed self-compatibility to reduce effects of pollen limitation, for example by infrequent pollinator visits and low pollination quality (Kunin et al. 1997, Ghazoul 2005). However, the high proportion of anemophily and selfincompatibility among successful target species was probably not the direct cause of colonisation success, as most of the successful species are tall Poaceae with high frequencies in the REF sites.

More of the successful species had runners and rhizomes than of the unsuccessful species. These modes of propagation could have offered them a competitive advantage during colonisation.

Surprisingly, dispersal type did not show any correlation with colonisation success. Contrary to our expectations, $50 \%$ of unsuccessful species were wind-dispersed, which should have facili- tated their rapid dispersal. Again, it is likely that this trait was not a direct predictor for success but that it covaried with the more important trait of plant height (Lauterbach et al. 2013). For example, the tall and animal-dispersed Dactylis glomerata was a successful coloniser, while the smaller and wind-dispersed Briza media was unsuccessful even over short distances.

\section{CONCLUSIONS}

Our study showed that in the first four years after site preparation, most target species failed to reach the restoration sites or began to colonise it only in the immediate vicinity of the donor sites. This result shows that colonisation in passively restored semi-dry grasslands is a slow process, even when sites border directly on donor areas.

Most successful colonisers were competitive and tall species of the Arrhenatherion alliance. By contrast, small species with low competitive ability and high conservation value were not very successful within this period of time.

If the succession trend continues, there is danger that sites develop into species-poor $A r$ rhenatherion meadows, rather than into speciesrich semi-dry grasslands. Although the restoration project is at a very early phase, it already shows signs that additional measures might be necessary to deplete soil nutrients and provide microsites for seed establishment through management intensification and/or adaption.

In summary, spontaneous colonisation might be a valuable option in semi-dry grassland restoration, particularly when the restoration site is situated adjacently and within a perimeter of 10-15 m to proper donor sites. However, practitioners should implement additional measures to increase restoration success:

1. When using spontaneous colonisation as a restoration tool, practitioners should prepare a site by ploughing. Closed swards will inhibit natural colonisation.

2. Rare, small, stress-adapted species are poor colonisers. Practitioners should introduce them actively through seeding at the beginning of the restoration project.

3. In order to remove nutrients to provide favourable conditions also for small, stress-tolerant species, restored semi-dry grasslands should be mowed twice in the course of the growing season. 


\section{ACKNOWLEDGMENTS}

We would like to thank Josef Hafellner and Christian Berg for constructive comments on the manuscript. We also express gratitude to the EDGG and IAVS for funding the linguistic editing by Laura Sutcliffe.

\section{REFERENCES}

Anonymus 2012a: eBod. Retrieved from http:// gis.lebensministerium.at/eBOD/frames/index.php?\&146=true\&gui_id=eBOD (accessed 24.02.2012).

Anonymus 2012b: ZAMG: Klimadaten von Österreich 1971-2000. Retrieved from http:// www.zamg.ac.at/fix/klima/oe 7100/klima2000/klimadaten_oesterreich_1971_frame1.htm (accessed 24.02.2012).

Bartha, S., Meiners, S. J., Pickett, S. T. A., Cadenasso, M. L., Scott, J., Steward, T. A. \& Mary, L. 2003: Plant colonization windows in a mesic old field succession. Applied Vegetation Science 6: 205-212.

Braun-Blanquet, J. 1964: Pflanzensoziologie: Grundzüge der Vegetationskunde (3rd ed.). Springer Verlag, Wien, 865 pp.

Briemle, G., Nitsche, S. \& Nitsche, L. 2002: Nutzungswertzahlen für Gefäßpflanzen des Grünlandes. Schriftenreihe für Vegetationskunde 38: 203-225.

Clark, D. L., Wilson, M., Roberts, R., Dunwiddie, P. W., Stanley, A. \& Kaye, T. N. 2012: Plant traits - a tool for restoration? Applied Vegetation Science 15: 449-458.

Conrad, M. K. \& Tischew, S. 2011: Grassland restoration in practice: Do we achieve the targets? A case study from Saxony-Anhalt/Germany. Ecological Engineering 37: 1149-1157.

Di Pietro, R. 2011: New dry grassland associations from the Ausoni-Aurunci mountains (Central Italy) - Syntaxonomical updating and discussion on the higher rank syntaxa. Hacquetia 10: 183-231.

Dierschke, H. 1994: Pflanzensoziologie: Grundlagen und Methoden. Eugen Ulmer, Stuttgart, $683 \mathrm{pp}$.

Dierschke, H. 1995: Phänologische und symphänologische Artengruppen von Blütenpflanzen in Mitteleuropa. Tuexenia 15: 523 - 560 .

Donath, T. W., Bissels, S., Hölzel, N. \& Otte, A. 2007: Large scale application of diaspore transfer with plant material in restoration practice - Impact of seed and microsite limitation. Biological Conservation 138: 224-234.

Donath, T. W., Hölzel, N., Otte, A. \& Tobias, W. 2003: The impact of site conditions and seed dispersal on restoration success in alluvial meadows. Applied Vegetation Science 6: 13-22.

Dostálek, J. \& Frantík, T. 2008: Dry grassland plant diversity conservation using low-intensity sheep and goat grazing management: case study in Prague (Czech Republic). Biodiversity and Conservation 17 (6): 1439-1454.

Ellenberg, H., Weber, H. E., Düll, R., Wirth, V., Werner, W. \& Paulißen, D. 1991: Zeigerwerte von Pflanzen in Mitteleuropa. Scripta Geobotanica 18: 1-248.

Eriksson, O. \& Jakobsson, A. 1998: Abundance, distribution and life histories of grassland plants : a comparative study of 81 species. Journal of Ecology 86: 922-933.

ESRI 2012: ArcGIS Desktop: Release 10.1. Redlands, CA: Environmental Systems Research Institute.

Essl, F., Egger, G., Karrer, G., Theiss, M. \& Aigner, S. 2004: Rote Liste der gefährdeten Biotoptypen Österreichs. Grünland, Grünlandbrachen und Trockenrasen, Hochstaudenund Hochgrasfluren, Schlagfluren und Waldsäume, Gehölze des Offenlandes und Gebüsche. Monographien des Umweltbundesamtes Wien 167: 1-272.

Fagan, K. C., Pywell, R. F., Bullock, \& Marrs, J. M. 2008: Do restored calcareous grasslands on former arable fields resemble ancient targets? The effect of time, on outcomes methods and environment on outcomes. Journal of Vegetation Science 45: 1293-1303.

Fischer M. A., Oswald, K. \& Adler, W. 2008: Exkursionsflora für Österreich, Liechtenstein und Südtirol (3rd ed.). Land Oberösterreich, Oberösterreichische Landesmuseen, Linz, $1392 \mathrm{pp}$.

Fischer, L. K., von der Lippe, M. \& Kowarik, I. 2013: Urban grassland restoration: which plant traits make desired species successful colonizers? Applied Vegetation Science 16: 272-285.

Fischer, M. \& Stöcklin, J. 1997: Local extinctions of plants in remnants of extensively used calcareous grasslands 1950-1985. Conservation Biology 11: 727-737.

Gepp, J. 1986: Trockenrasen in Österreich als schutzwürdige Refugien wärmeliebender Tier- 
arten. In: Holzner, W. (ed.): Österreichischer Trockenrasenkatalog. Grüne Reihe des Bundesministeriums für Gesundheit und Umweltschutz 6: 1-380.

Ghazoul, J. 2005: Pollen and seed dispersal among dispersed plants. Biological Reviews of the Cambridge Philosophical Society 80: 413-443.

Grime, J. P. 1979: Plant strategies and vegetation processes. Wiley, Chichester, $222 \mathrm{pp}$.

Habel, J. C., Dengler, J., Janišová, M., Török, P., Wellstein, C. \& Wiezik, M. 2013: European grassland ecosystems: threatened hotspots of biodiversity. Biodiversity and Conservation 22: 2131-2138.

Hansson, M. \& Fogelfors, H. 2000: Management of a semi-natural grassland: results from a 15-year-old experiment in southern Sweden. Journal of Vegetation Science 11: 31-38.

Hejcman, M., Klaudisová, M., Schellberg, J. \& Honsová, D. 2007: The Rengen Grassland Experiment: Plant species composition after 64 years of fertilizer application. Agriculture, Ecosystems \& Environment 122: 259-266.

Hennekens, S. M. \& Schamineé, J. H. J. 2001: TURBOVEG, a comprehensive database management system for vegetation data. Journal of Vegetation Science 12: 589-591.

IBM Corp. Released 2012: IBM SPSS Statistics for Windows, Version 21.0. Armonk, NY: IBM Corp.

Igic, B., Lande, R. \& Kohn, J. R. 2008: Loss of self-incompatibility and its evolutionary consequences. International Journal of Plant Sciences 169: 93-104.

Jacquemyn, H., Van Mechelen, C., Brys, R. \& Honnay, O. 2011: Management effects on the vegetation and soil seed bank of calcareous grasslands: An 11-year experiment. Biological Conservation 144: 416-422.

Janssens, F., Peeters, A., Tallowin, J. R. B., Bakker, J. P., Bekker, R. M., Fillat, F. \& Oomes, M. J. M. 1998: Relationship between soil chemical factors and grassland diversity. Plant and Soil 202: 69-78.

Jírová, A., Klaudisová, A. \& Prach, K. 2012: Spontaneous restoration of target vegetation in old-fields in a central European landscape: a repeated analysis after three decades. Applied Vegetation Science 15: 245-252.

Kahmen, S. \& Poschlod, P. 2004: Plant functional trait responses to grassland succession over 25 years. Journal of Vegetation Science 15: 21-32.
Kahmen, S., Poschlod, P. \& Schreiber, K.-F. 2002: Conservation management of calcareous grasslands. Changes in plant species composition and response of functional traits during 25 years. Biological Conservation 104: 319-328.

Kelemen, A., Török, P., Valkó, O., Deák, B., Miglécz, T., Tóth, K., Ölvedi, T. \& Tóthmérész, B. 2014: Sustaining recovered grasslands is not likely without proper management: vegetation changes after cessation of mowing. Biodiversity and Conservation 23: 741-751.

Kirmer, A. \& Mahn, E.-G. 2001: Spontaneous and initiated succession on unvegetated slopes in the abandoned lignite-mining area of Goitsche, Germany. Applied Vegetation Science 4: 19-27.

Kirmer, A., Mann, S., Stolle, M., Krautzer, B., Graiss, W., Haslgrübler, P. \& Scotton, M. 2012: Techniques for the establishment of species-rich grasslands. In: Scotton, M. A., Kirmer, A. \& Krautzer, B. (eds.): Practical handbook for seed harvest and ecological restoration of species-rich grasslands. Cooperativa Libraria Editrice Universitá di Padova, Padova, pp. 43-58.

Klotz, S., Kühn, I. \& Durka, W. (eds.) 2002: BIOLFLOR - Eine Datenbank zu biologischökologischen Merkmalen der Gefäßpflanzen in Deutschland. Schriftenreihe für Vegetationskunde 38: 1-344.

Kunin, William, E. \& Shmida, A. 1997: Plant reproductive traits as a function of local, regional and global abundance. Conservation Biology 11: 183-192.

Landolt, E. (ed.) 2010: Flora Indicativa: Ökologische Zeigerwerte und biologische Kennzeichen zur Flora der Schweiz und der Alpen. Haupt-Verlag, Bern, 378 pp.

Lauterbach, D., Römermann, C., Jeltsch, F. \& Ristow, M. 2013: Factors driving plant rarity in dry grasslands on different spatial scales: a functional trait approach. Biodiversity and Conservation 22: 2337-2352.

Lawson, C. S., Ford, M. A., Mitchley, J., Clare, S. \& Martin, A. 2004: The influence of seed addition and cutting regime on the success of grassland restoration on former arable land. Applied Vegetation Science 7: 259-266.

Moles, A. T. \& Westoby, M. 2004: Seedling survival and sees size: a synthesis of the literature. Journal of Ecology 92: 372-383.

Paušič, A. \& Čarni, A. 2012: Functional response traits and plant community strategy indicate 
the stage of secondary succession. Hacquetia 11: 209-225.

Pipenbaher, N., Kaligarič, M., Mason, N. W. H. \& Škornik, S. 2013: Dry calcareous grasslands from two neighbouring biogeographic regions: relationship between plant traits and rarity. Biodiversity and Conservation 22: 2207-2221.

Prach, K. \& Hobbs, R. J. 2008: Spontaneous succession versus technical reclamation in the restoration of disturbed sites. Restoration Ecology 16: 363-366.

Prach, K. \& Pyšek, P. 1999: How do species dominating in succession differ from others? Journal of Vegetation Science 10: 383-392.

Prach, K., Lencová, K., Rehounková, K., Dvořáková, H., Jírová, A., Konvalinková, P., Mundrák, O., Novák, J. \& Trnková, R. 2013: Spontaneous vegetation succession at different central European mining sites: a comparison across seres. Environmental Science and Pollution Research International 20: 7680-7685.

Pywell, R. F., Bullock, J. M., Roy, D. B., Warman, L., Walker, K. J. \& Rothery, P. 2003: Plant traits as predictors of performance in ecological restoration. Journal of Applied Ecology 40: 65-77.

Römermann, C., Tackenberg, O., Jackel, A.-K. \& Poschlod, P. 2007: Eutrophication and fragmentation are related to species' rate of decline but not to species rarity: results from a functional approach. Biodiversity and Conservation 17: 591-604.

Ruprecht, E. 2006: Successfully recovered grassland: a promising example from Romanian old-fields. Restoration Ecology 14: 473-480.

Ruprecht, E. \& Szabó, A. 2012: Grass litter is a natural seed trap in long-term undisturbed grassland. Journal of Vegetation Science 23: 495-504.

Sengl, P. \& Magnes, M. 2008: Halbtrockenrasen in St. Anna am Aigen (Südoststeiermark) Relikte einer gefährdeten Kulturlandschaft. Mitteilungen des Naturwissenschaftlichen Vereines für Steiermark 138: 255-286.

Stampfli, A. \& Zeiter, M. 1999: Plant species decline due to abandonment of meadows cannot easily be reversed by mowing. A case study from the southern Alps. Journal of Vegetation Science 10: 151-164.

Steinbuch, E. 1995: Wiesen und Weiden der Ost-, Süd- und Weststeiermark. Dissertationes Botanicae 253: 1-210.

Sturges, H.A. 1926: The choice of a class interval.
Journal of the American Statistical Association 21: 65-66.

Thomson, F. J., Moles, A. T., Auld, T. D. \& Kingsford, R. T. 2011: Seed dispersal distance is more strongly correlated with plant height than with seed mass. Journal of Ecology 99: 1299-1307.

Tichý, L. 2002: JUICE, software for vegetation classification. Journal of Vegetation Science 13: 451-453.

Tichý, L. 2005: New similarity indices for the assignment of relevés to the vegetation units of an existing phytosociological classification. Plant Ecology 179: 67-72.

Tischew, S., Baasch, A., Grunert, H. \& Kirmer, A. 2013: How to develop native plant communities in heavily altered ecosystems: examples from large-scale surface mining in Germany. Applied Vegetation Science 17: 288-301.

Török, P., Vida, E., Deák, B., Lengyel, S. \& Tóthmérész, B. 2011: Grassland restoration on former croplands in Europe: an assessment of applicability of techniques and costs. Biodiversity and Conservation 20: 2311-2332.

Trnková, R., Rehounková, K. \& Prach, K. 2010: Spontaneous succession of vegetation on acidic bedrock in quarries in the Czech Republic. Preslia 82: 333-343.

WallisDeVries, M. F., Poschlod, P. \& Willems, J. H. 2002: Challenges for the conservation of calcareous grasslands in northwestern Europe: integrating the requirements of flora and fauna. Biological Conservation 104: 265-273.

Willner, W. 2007a: Carpinion betuli Issler 1931. In: Willner, W. \& Grabherr, G. (eds.): Die Wälder und Gebüsche Österreichs. Band 1. Elsevier, Heidelberg, pp. 137-144.

Willner, W. 2007b: Quercetalia roboris Tx. 1931. In: Willner, W. \& Grabherr, G. (eds.): Die Wälder und Gebüsche Österreichs. Band 1. Elsevier, Heidelberg, pp 109-112.

Willner, W., Sauberer, N., Staudinger, M., Grass, V., Kraus, R., Moser, D., Rötzer, H. \& Wrbka, T. 2013: Syntaxonomic revision of the Pannonian grasslands of Austria - Part II: Vienna Woods (Wienerwald). Tuexenia 33: 421-458.

Wilson, J. B., Peet, R. K., Dengler, J. \& Pärtel, M. 2012: Plant species richness: the world records. Journal of Vegetation Science 23: 796-802.

Received: 30 April 2014 Accepted: 18 November 2014 Co-ordinating Editor: Marta Carboni 